\title{
Communication Competency in Foreign Languages and Digital Competency in Life Sciences Course Book
}

\author{
Sevgi Yüksel ${ }^{1} \&$ Ahu Taneri ${ }^{2, *}$ \\ ${ }^{1}$ National Education Directorate of Selçuklu District, Konya, Turkey \\ ${ }^{2}$ Niğgde Ömer Halisdemir University, Niğde, Turkey \\ *Correspondence: Niğde Ömer Halisdemir University, Niğde, Turkey. E-mail: ahutaneri@ohu.edu.tr
}

Received: May 12, $2020 \quad$ Accepted: June 11, $2020 \quad$ Online Published: August 22, 2020

doi:10.5430/jct.v9n3p190 URL: https://doi.org/10.5430/jct.v9n3p190

This research is based on the master's thesis composed by Sevgi YÜKSEL under the supervision of Lecturer Dr. Ahu TANERİ

\begin{abstract}
This study aims to analyze to what extent the competency of 'Communication in Foreign Languages' and 'Digital Competency' which are addressed in Turkish Qualifications Framework and instruction programs in Turkey are covered by life sciences course books. The research was performed through the case study method which was within the context of qualitative research models. In the study, life sciences course books which were selected through convenience sampling, approved by the Board of Instruction and Education of the Ministry of National Education of Turkey and used in the first, second and third years of primary schools in the school year of 2018-2019 were examined. As per results obtained from research findings, it was found that the competency of 'Communication in Foreign Languages' and 'Digital Competency' were insufficiently referred to in course books. On the basis of research findings, recommendations intended for designers, teachers and researchers of instruction programs of life sciences course were presented.
\end{abstract}

Keywords: life sciences, course books, key competencies

\section{Introduction}

Lifelong learning is a concept stressed persistently by the European Union alongside the gradual growth of the importance of information, the transformation in the area of economy and demographic reasons such as aging population. According to European Parliament, lifelong learning is about all learning activities fulfilled across life for enhancing individual's knowledge base, skills and competencies (European Parliament \& the Council of Europe, 2006: 2).

The concept of lifelong learning gained prominence also in Turkey in recent years. 'Lifelong Learning Strategy Paper of Turkey for the Period of 2009-2013' was composed in 2009, and all sorts of learning activities attended by the individual all through life for enhancing knowledge base, skills, interests and qualifications on the basis of a personal, societal, social and employment-oriented approach were defined as the lifelong learning by the Ministry of National Education of Turkey. Through National Lifelong Learning Strategy Paper for the Period of 2014-2018 which was composed in 2014, lifelong learning programs were transformed into a more systematic structure (Ministry of National Education of Turkey, 2014: 5).

Globalization, rapid change in information and communication technologies and the effect of such changes on production and economic life oblige individuals to modernize themselves and adapt to changing conditions. Therefore, individuals must constantly enhance their qualifications so that they can adapt to such changes, meet the needs of the world of economy and become more productive in economic life. In this respect, lifelong learning is an obligation for each individual.

Member States of the European Union agreed in 2004 to develop a qualifications framework which would act as a reference point for the promotion of occupational education and instruction. On April 23, 2008, the European 
Qualifications Framework for lifelong learning was created by the European Parliament and the Council of Europe (Gözübüyük, 2013: 44).

The European Qualifications Framework identifies eight key competencies supposed to be obtained by each individual and specifies knowledge, skills and behaviors related to each competency. These competencies were listed as 'communication in mother tongue', 'communication in foreign languages', 'mathematical competency and key competencies in science/technology', 'digital competency', 'learning to learn', 'social and civic competencies', 'sense of initiative and entrepreneurship' and 'cultural awareness and expression'.

The European Qualifications Framework aims to support lifelong learning, to enable students and labor force of member states to move freely and to obtain jobs across the European Union and to encourage exchanges between educational institutions within the European Union by creating a common reference point for national and sector-specific qualifications. Bringing the European Qualifications Framework into action across Europe is possible only if member and candidate countries adapt their national frameworks to it.

The Turkish Qualifications Framework was designed in a manner to be compatible with above competencies upon the Recommendation on the European Qualifications Framework for lifelong learning, and was defined as the national qualifications framework which indicated all essential qualifications obtained through occupational, general and academic education and instruction programs including primary, secondary and tertiary education and other means of learning (Vocational Qualifications Authority of Turkey, 2015: 2-3)

The key function of the Turkish Qualifications Framework is to define qualifications in terms of learning achievements and to present the opportunity for inter-comparison of qualifications. The Turkish Qualifications Framework will act as the driving force in facilitating the improvement, modernization and international comparability of the education and instruction system of Turkey and in enabling other countries to get to know Turkey better. The change to be induced in education and instruction system of Turkey by the implementation of the Turkish Qualifications Framework and by the involvement of stakeholders will be useful for raising the popularity of lifelong learning, meeting expectations of the society and business world and accelerating the transition from industrial society to information society.

Eight key competencies defined in the European Qualifications Framework for the purpose of advocating lifelong learning were incorporated into the Turkish Qualifications Framework. In all instruction programs designed in 2018, the Turkish Qualifications Framework and key competencies were explained, and it was emphasized that, as well as skills to be attained by individuals through the delivery of education and instruction, individuals should be equipped with qualifications and skills which defined these qualifications.

Students need to upgrade their competency levels constantly so that they can adapt to changes, meet the requirements of the era and be more productive in societal and economic life. Therefore, the incorporation of key competencies covered by lifelong learning into instruction programs and the development of these key competencies in a manner to be beneficial to all individuals turned to be an obligation. In this context, it is strategically important to promote lifelong learning at school settings, include it in instruction programs and course books and to raise the awareness of teachers about the uses of these competencies.

In the educational system reorganized as response to the needs of changing modern conditions, books always continue to be important to students and teachers. A well-prepared course book is quite helpful for both the student and teacher. It acts as a guide for the teacher in instructional activities and helps to diversify these activities. As it establishes links between previous and current teachers and is an easily accessible learning material, it is also important to the student (Güçlü, 2001: 20-22).

Schools, instruction programs and instructional activities play crucial roles in attaining success in lifelong learning. For both childhood period and subsequent periods, it is quite important to include key competencies in course contents within the context of lifelong learning and, by organizing learning activities on this basis, to assure that children succeed in obtaining the relevant achievements. Therefore, in the context of achieving lifelong learning, the identification of the level of success in the transfer of key competencies to the learning setting in life sciences course through course books will be a significant factor for empowering schools to adapt to the era and for enabling students to be successful. However, results obtained from international studies demonstrate that there are significant shortcomings of several students in attaining lifelong learning qualifications. It is important to systematically identify to what extent key competencies of lifelong learning are addressed in life sciences course content.

In order to reach this goal, this research endeavored to seek answer to the following question: 'In terms of class year and course book unit, how is the distribution of the competency of 'Communication in Foreign Languages' and 
'Digital Competency' addressed as per the Turkish Qualifications Framework in life sciences course books of the school year of 2018-2019?' Sub-questions specified in relation to the research question are as below:

1. In terms of class year and course book unit, how is the competency of 'Communication in Foreign Languages' is distributed in life sciences course books?

2. In terms of class year and course book unit, how is 'Digital Competency' is distributed in life sciences course books?

\section{Methodology}

In this study, the competency of 'Communication in Foreign Languages' and 'Digital Competency' were scrutinized across texts of life sciences course books in terms of class year and course book unit. In order to find out these key competencies, qualitative research method was utilized. In this respect, case study design was employed in the research.

\subsection{Sampling}

Convenience sampling was used in the study for the sample selection. Research sample was comprised of life sciences course books which teachers frequently preferred to use at primary schools in several provinces across Turkey in the school year of 2018-2019. The First Year Life Sciences Course Book (Kök-e Publication), the Second Year Life Sciences Course Book (Sdr İpekyolu Publication) and the Third Year Life Sciences Course Book (Publication of the Ministry of National Education of Turkey) provided the data base for the research.

\subsection{Data Collection Tool}

In order to obtain research data, texts of the first year, second year and third year life sciences course books were examined in terms of the competency of 'Communication in Foreign Languages' and 'Digital Competency'. Texts were examined on the basis of 'Turkish Qualifications Framework'.

\subsection{Analysis of Data}

The document examination form was employed for identifying the competency of 'Communication in Foreign Languages' and 'Digital Competency' which existed in life sciences course books. To this end, firstly, the digital versions of life sciences course books were obtained. Key words specified in the document examination form were searched in digital versions of course books for multiple times, and data obtained by this search were inserted to Microsoft Excel 2010 software, and frequency and percentage values were calculated for data.

\subsection{Validity and Reliability Test}

In order to enhance the validity and reliability of qualitative aspect of this research, sufficient time was allocated to data collection and analysis, and, moreover, data collection and analysis were continued until a certain level of satisfaction was reached for assuring the internal validity in light of suggestions by Miles and Huberman (1994: 64), Yıldırım and Şimşek (2018: 87-88) and Patton (2014: 541). Furthermore, in order to enhance the external reliability of the research, attempts were made to explain in detail the research process and efforts made during the research process.

\section{Findings}

\subsection{Findings on the First Sub-question}

Table 1 displayed findings on the first sub-question of the research which was as follows: "How is the competency of 'Communication in Foreign Languages' is distributed in life sciences course books in terms of class year and course book unit?”

Upon the review of Table 1, it is discerned that the competency of 'Communication in Foreign Languages' is referred to in five sentences in the first and third year life sciences course books and in four sentences in the second year life sciences course book. Certain examples were presented below for the competency of 'Communication in Foreign Languages' which was mentioned in certain units.

"Turkey is also my country from now on. I learn Turkish language from my friends. In return, I teach them German language." (First Year, Unit titled 'Life in Our Country', p. 156)

"Today, I met big sister Nurcahan who was our neighbor. She came from Turkmenistan, and studies at university." (First Year, Unit titled 'Life in Our Country', p. 174) 
"I ran to him. He failed to understand me when I asked the following: 'Would you like to play with us?' He was capable of saying only the following statement 'My name is Imad.' and he was able to state the name of his country. It seemed that he just started to learn our language." (Third Year, Unit titled 'Life in Our Country', p. 136)

The review of Table 1 on the basis of course book units demonstrates that the competency of 'Communication in Foreign Languages' is covered only by the unit titled 'Life in Our Country' across all class years. Besides, it was ascertained that this competency was not addressed in any other unit.

Table 1. The Breakdown of the Competency of 'Communication in Foreign Languages' by Class Year and Course Book Unit

\begin{tabular}{|c|c|c|c|c|c|c|}
\hline \multirow{2}{*}{ Unit } & \multicolumn{2}{|c|}{ First Year (n) } & \multicolumn{2}{|c|}{ Second Year (n) } & \multicolumn{2}{|c|}{ Third Year (n) } \\
\hline & $\mathrm{f}$ & $\%$ & $\mathrm{f}$ & $\%$ & $\mathrm{f}$ & $\%$ \\
\hline Life in Our School & 0 & 0 & 0 & 0 & 0 & 0 \\
\hline Life in Our House & 0 & 0 & 0 & 0 & 0 & 0 \\
\hline Healthy Life & 0 & 0 & 0 & 0 & 0 & 0 \\
\hline Secure Life & 0 & 0 & 0 & 0 & 0 & 0 \\
\hline Life in Our Country & 5 & 100 & 4 & 100 & 5 & 100 \\
\hline Life in Nature & 0 & 0 & 0 & 0 & 0 & 0 \\
\hline Total & 5 & $\% 100$ & 4 & $\% 100$ & 5 & $\% 100$ \\
\hline
\end{tabular}

\subsection{Findings on the Second Sub-question}

Table 2 showed findings on the second sub-question of the research which was as follows: "How is "Digital Competency' distributed in life sciences course books in terms of class year and course book unit?"

Table 2. The Breakdown of 'Digital Competency' by Class Year and Course Book Unit

\begin{tabular}{lcccccc}
\hline \multirow{2}{*}{ Unit } & \multicolumn{3}{c}{ First Year $(\mathrm{n})$} & \multicolumn{2}{c}{ Second Year $(\mathrm{n})$} & \multicolumn{2}{c}{ Third Year $(\mathrm{n})$} \\
\cline { 2 - 7 } & $\mathrm{f}$ & $\%$ & $\mathrm{f}$ & $\%$ & $\mathrm{f}$ & $\%$ \\
\hline Life in Our School & 0 & 0 & 0 & 0 & 0 & 0 \\
Life in Our House & 0 & 0 & 0 & 0 & 1 & 20 \\
Healthy Life & 0 & 0 & 0 & 0 & 3 & 60 \\
Secure Life & 13 & 100 & 7 & 100 & 1 & 20 \\
Life in Our Country & 0 & 0 & 0 & 0 & 0 & 0 \\
Life in Nature & 0 & 0 & 0 & 0 & 0 & 0 \\
\multicolumn{1}{c}{ Total } & 13 & $\% 100$ & 7 & $\% 100$ & 5 & $\% 100$ \\
\hline
\end{tabular}

Upon the review of Table 2, it is observed that 'Digital Competency' is addressed in thirteen sentences in the first year life sciences course book, in seven sentences in the second year life sciences course book and in five sentences in the third year life sciences course book. Certain examples were given below for 'Digital Competency' which was referred to in certain units.

"Television, computer and telephone are communication devices which we use at home. We should be careful when we use these devices." (First Year, Unit titled 'Secure Life', $p$. 107)

"Today, one of the devices which we use most frequently is the computer. By performing researches through computer with the help of internet, we acquire new information." (First Year, Unit titled 'Secure Life', p. 133)

"Technology became a part of our life. Technological devices and appliances which we use in our houses and schools facilitate our life. Computer, television and mobile phone are among technological devices which we use. When we make use of technological devices and appliances, we should make efforts to use them safely. In public networks, we must not communicate with people whom we do not know. We should use public network addresses which are safe for us." (Second Year, Unit titled 'Secure Life', p. 137)

"Defne and her friends had watched a video on energy saving during the course today." (Third Year, Unit titled 'Life in Our House', p. 67)

The review of Table 2 on the basis of course book units indicates that 'Digital Competency' is covered only by the unit titled 'Secure Life' in the first and second years and by units titled 'Life in Our House', 'Healthy Life' and 
'Secure Life' in the third year. On the other hand, it was discerned that this competency was not referred to in any other unit.

\section{Results and Discussion}

\subsection{Results and Discussion on the Breakdown of the Competency of 'Communication in Foreign Languages' by} Class Year and Course Book Unit

It was found that the competency of 'Communication in Foreign Languages' was addressed in each class year only by the unit titled 'Life in Our Country'. This result demonstrates that life sciences course books are not in a position to contribute to the development of positive attitudes which are within the context of this competency and expected of individuals such as the respect toward cultural diversity, willingness to promote interaction between cultures. Moreover, departing from the fact that the concept of competency signifies high-level skills, it can be asserted that knowledge-type statements included in life sciences course books and establishing relationships only with one unit will be insufficient for endowing students with the competency of 'Communication in Foreign Languages'.

In a world in which communication distances are reduced along with technological progress, addressing skills in relation to foreign language through a single course or in a limited scope will give rise to problems in terms of equipping students with the competency in this field (Akkoyunlu \& Soylu, 2010: 748). As per this study, the unbalanced distribution of the competency of 'Communication in Foreign Languages' across class years and course book units can also be related to the qualifications of staff that are involved with this endeavor (course book writer, expert, editor). The result of the study by Akkoyunlu and Soylu which suggested that teachers had high levels of motivation but limited foreign language skills demonstrates the inevitability of having certain problems which are included within the instructional material and associated with skills of teachers responsible for writing course books. It is considered that the acquisition of skills necessary for being able to raise individuals capable of making contributions to the society and culture during life sciences course will be possible by processing the competency of 'Communication in Foreign Languages' successfully during the instruction period besides other competencies defined in instruction programs. To this end, it can be asserted that staff that will be involved in writing course books should be selected from among people with foreign language skills well-suited to the responsibility to be assumed for parts on this competency.

It is known that, if students obtain the competency of 'Communication in Foreign Languages', they will develop high level skills as in the case of attaining the competency of 'Communication in Mother Tongue' (Paker, 2013: 89; Bakırc1 \& Kutlu, 2018: 367; Gelen, 2017: 15; Günay, 2011: 113). It can be said that blending intercultural communication with principles such as 'from near to distant', 'from known to unknown' and 'up-to-dateness' and then implanting it into all course topics are necessary for ensuring that competencies are attained (Gökmen, 2005: 69). It is discerned that the result obtained through this study and also findings reported previously in the relevant literature support each other. Toprak and Erdoğan (2012: 69) argue that presenting competencies availably in educational settings without structuring them will not be effective in enabling students to attain competencies. Structuring instruction programs and establishing relationships between different disciplines will have utmost importance to the attainment of the competency of 'Communication in Foreign Languages'.

\subsection{Results and Discussion on the Breakdown of 'Digital Competency' by Class Year and Course Book Unit}

Upon the review of 'Digital Competency' in life sciences course books in terms of class year and course book unit, it is discerned that 'Digital Competency' is not distributed in a balanced manner. The inclusion of this competency in course books and the need for guidance became even more significant along with the rise in the usage of technology in education by schools covered by FATIH Project (The Movement Toward Enhancing Opportunities and Improving Technology), the development of technological infrastructure in other schools and the obligation to use information and communication technologies.

Akkoyunlu and Soylu (2010: 748) assert that the positive attitude of experts and teachers toward the attainment of 'Digital Competency' played a key role. They allege that the encouragement of students by experts of course book commissions (essentially teachers) to use the technology in the proper manner by promoting the development of positive attitudes toward technology is likely to change the existing situation. The development of technology and its use in educational settings were presented in life sciences course books, however, the technological competency necessary for producing technology failed to get its desired place in course books. Addressing technological competency only in terms of its security aspect within the context of life sciences course revealed the fact that it would strictly place the focus on harmful effects of technology, rather than empowering students to attain this 
competency. This situation can tempt students to develop negative attitudes. In the context of 'Digital Competency', individuals must comprehend how Information Society Technology would support innovativeness and novelty. They should be informed about legal and ethical principles about the interactive use of Information Society Technology. It can be alleged that life sciences course books are far from being satisfactory in this sense.

Aydoğdu (2016) stresses the importance of technology use to the attainment of scientific process skills. Along with the balanced distribution of technological competencies across life sciences course books, the attainment of scientific process skills will also be facilitated (Toprak \& Erdoğan, 2012: 69; Gençel, 2013: 237). The study by Şad and Nalçacı (2015: 177) deduced that teachers (Course Book Writing Commission) in general perceived themselves to have the relevant digital competencies but did not have several key technological data in educational settings. It is thought that this situation could be one of the reasons for the unbalanced distribution which was identified in this study.

\section{Conclusion}

When teachers make instructional plans, they can try to equip students with Communication in Foreign Languages competency which is not covered by the course book at the desired level by urging students to perform activities likely to buttress students' personal, social and cultural development. Moreover, departing from societal experiences, the learning process can be organized in a way to be adapted for promoting the interaction between societies. In the context of lifelong learning, it is possible to create learning settings where students can practice the daily use of a foreign language which is likely to be helpful to them.

In order to endow students with digital competency which is not covered by course books at the desired level, teachers can urge their students to think in a critical and reflective manner about information existing in interactive media. So that students can perform secure researches, teachers can guide students and create learning settings requiring the technology use such as the access to information, the evaluation, storage, production, presentation and exchange of information.

\section{References}

Akkoyunlu, B., \& Soylu, Y. (2010). A study on teachers' numerical competencies. Turkish Librarianship, 24(4), 748-768.

Aydoğdu, B. (2006). Determination of variables affecting scientific process skills in primary school science and technology lesson (Doctoral Dissertation). DEU Institute of Educational Sciences, İzmir.

Bakırcı, H., \& Kutlu, E. (2018). Determining the views of science teachers about STEM approach. Turkish Journal of Computer and Mathematics Education, 9(2), 367-389. https://doi.org/10.16949/turkbilmat.417939

European Parliament and the Council of Europe. (2006). Action program in the field of lifelong learning (2004-2006). Official Journal of the European Union, L(327), 45-68.

Gelen, İ. (2017). P21-21st Century Skill Frameworks in Program and Teaching (US Applications). Journal of Interdisciplinary Educational Research, 1(2), 15-29.

Gencel, İ. E. (2013). Perceptions of teacher candidates towards lifelong learning competencies. Education and Science, 38(170), 237-252.

Gökmen, E. (2005). Intercultural communicative acquisition in foreign language teaching. Language Journal, (128), 69-77.

Gözübüyük Tamer, M. (2013). national competences for lifelong learning, frame: an example of Europe and Turkey. International Journal of Education Programs and Instructional Studies, 3(5), 43-54.

Güçlü, N. (2001). Design of the Life Science Textbook, edt. Leyla Küçükahmet, Ankara, 22-23.

Günay D. (2011) Problems, Trends, Principles and Suggestions in the Context of Turkish Restructuring of Higher Education. Journal of Higher Education and Science, 1(3), 113-121. https://doi.org/10.5961/jhes.2011.017

MEB (2014). Turkey lifelong learning strategy document. Ankara: Ministry of National Education. Vocational Qualifications Authority (2015). Turkey competency framework. Ankara.

Miles, M. B., \& Huberman, A. M. (1994). Qualitative data analysis: An expveed sourcebook. California: SAGE Publications. 
Paker, T. (2012). Why Turkey in Foreign Language (English) Why do not we teach our students English and could not learn in Level Contact? Pamukkale University Journal of Education, 32(32), 89-94. https://doi.org/10.9779/PUJE563

Patton, M. Q. (2014), Qualitative Research \& Evaluation Methods Integrating Theory and Practice. Sage Publications, Thousand Oaks, CA.

Şad, S. N., \& Nalçacı, Ö. I. (2015). Teacher Candidates' Competence Perceptions About Using Information and Communication Technologies in Education. Mersin University Journal of the Faculty of Education, 11(1), 166-197.

Toprak, M., \& Erdogan, A. (2012). Lifelong Learning: Concept, Policy, Instruments and Implementation. Journal of Higher Education and Science, 2(2), 69-91. https://doi.org/10.5961/jhes.2012.036

Yıldırım, A., \& Şimşek, H. (2018). Qualitative research methods in the social sciences. Ankara: Seçkin Publishing.

\section{Copyrights}

Copyright for this article is retained by the author(s), with first publication rights granted to the journal.

This is an open-access article distributed under the terms and conditions of the Creative Commons Attribution license (http://creativecommons.org/licenses/by/4.0/). 